\title{
Narrativas comunitárias e pré-textos identitários (o caso Malê)
}

\section{RESUMO}

A partir da análise de um escrito malê, se pretende aqui apreender a estrutura discursiva subjacente a todo projeto comunitário e desvelar a dimensão narrativa que "modela" seu ethos e o inscreve no mito fundador responsável por seu enraizamento no passado e sua projeção para o futuro. Uma das teses defendidas neste trabalho é relativa à dupla virtualidade de todo projeto comunitário: de um lado, no sentido da precedência de sua pregnância e potencialidade discursiva sobre sua manifestação material concreta e, por outro, precisamente no caso religioso, enquanto "práxis" e "poiesis" a-espaciais e atemporais instituídas numa fala original e uma narratividade primordial, eterna e onipresente.

\section{PALAVRAS-CHAVE}

- identidade

- cultura

- discurso

\section{ABSTRACT}

Based on the analysis of a malê writing, it is intended here, to approach the discursive structure underlying all community project, and to reveal the narrative dimension that models its ethos and inscribes it in the founder myth responsible for its rooting in the past and its projection into the future. One of the exposed thesis in this paper is relative to the double virtuality of all community project: on one hand, in the sense of the precedence of its pregnancy and discursive potentiality over its concrete material manifestation and, on the other hand, precisely in the religious case, as a-spatial and a-temporal práxis and poiesis instituted in an original speech and a primordial, eternal and omnipresent narrative.

\section{KEY WORDS}

- identity

- culture

- discourse
0 presente artigo é fruto da tradução (do árabe para o português), análise e comentário de um livro de orações marabúticas ${ }^{1}$ corânicas (102 páginas de tamanho pequeno) encontrado pendurado sob forma de talismã no pescoço de um escravo africano rebelado e morto durante o levante malê ${ }^{2}$ ocorrido na Bahia em 1835. Nossa proposta é tentar apreender, a partir deste caso histórico, a estrutura discursiva subjacente a todo projeto comunitário e desvelar a dimensão narrativa que "modela" seu ethos $^{3}$ e o inscreve no mito fundador responsável por seu enraizamento no passado e sua projeção para o futuro - ainda que a problemática do Tempo, no contexto mítico-mitológico e religioso, seja bastante complexa como o demonstramos mais adiante.

\section{A modelagem discursiva}

Uma das teses defendidas por este trabalho é relativa à dupla virtualidade de todo projeto comunitário: de um lado, no sentido da precedência de sua pregnância e potencialidade discursiva sobre sua manifestação material concreta e, por outro, precisamente no caso religioso, enquanto "práxis" e "poiesis" a-espaciais e atemporais instituídas numa fala original e uma narratividade primordial, eterna e onipresente.

Com respeito ao Livro analisado, como foi conservado, se percebe que seu texto foi organizado de modo invertido, da esquerda à direita, ignorando o fato que o alfabeto árabe se escreve da direita à esquerda. A dificuldade inicial, portanto, foi de descobrir o sentido (no sentido material) da leitura, e somente após várias e repetidas leituras e tentativas de decifração que ficou claro que se tratava de trechos do Alcorão compilados sob a forma de uma narrativa reconstruída e reconfigurada; seguindo nisto uma longa tradição de orações islâmicas marabúticas e sufis.

Mas, antes de abordar o aspecto semântico do texto, há de levantar algumas considerações em torno da grafia ou "khat" (linha; radical do mesmo termo que dá a palavra alkhaiat ou alfaiate em português, mas também Khitab ou discurso) usada no livro male. A decifração de qualquer documento escrito em árabe é, de fato, condicionada pelo conhecimento e a familiaridade com o "khat" nele usado. Como as variadas grafias do árabe têm um caráter formal regional (o maghribi - magrebino, por exemplo é bastante diferente do kufi ou as grafias usadas para codificar o urdu ou o parsi), não é fácil ler e decifrar documentos escritos em grafias às quais não se é acostumado.

O "khat" utilizado no livro é, justamente, o "maghribi" (pertencente ao Magrebe - parte ocidental do norte da África). De fato, como se sabe, esse

\section{Mohammed ElHaiji ECO/UFRJ}


"khat", originário de Kayrawane (capital espiritual da Tunísia), foi introduzido na África ocidental e uma parte da África central pelos comerciantes e marabutos ou morábitos berberes. Até hoje, essa mesma grafia continua sendo usada em toda África ocidental , inclusive pelos haussá, iorubas islamizados e outros povos da região. ${ }^{4}$

Por outro lado, há de salientar a boa qualidade da ortografia; o que denota um importante domínio da língua árabe e um nível de instrução dos autores (se trata provavelmente de mais de um) acima da média. Exceto alguns erros menores, que se pode atribuir a fatores materiais (iluminação, por exemplo) ou psicológicas (cansaço, distração, etc.), a qualidade da ortografia não deixa dúvida quanto ao contexto social e cultural (educativo) no qual o escrito foi elaborado.

Já o texto propriamente dito do "Livro Malê" é, quase na sua totalidade, uma recomposição temática variada a partir do texto do Alcorão. Trata-se, na verdade, de uma "refiguração" textual (no sentido dado a esse conceito por Paul Ricoeur ${ }^{5}$ ) do Livro Sagrado. Ou seja, são trechos escolhidos do Alcorão (em função de uma tradição temática-situacional islâmica marabútica e sufi) que, lidos na nova recomposição e nova ordenação, produzem uma narrativa atualizada que situa um fato social dado (no caso, o episódio histórico da presença malê no Brasil) numa perspectiva mítica - atual na qual a experiência política e social se torna um desdobramento atualizado/recontextualizado das estórias bíblicas, dos ensinamentos divinos e da própria idéia da Umma islâmica.

Em seu uso simbólico social, o "Livro..." pode ter uma função protetora de Hijab (talismã); já que esse tipo de utilização (refigurada) do texto corânico é um hábito místico comum na cultura marabútica islâmica, principalmente nas regiões de influência sufi - o que é o caso em toda África do Norte e Ocidental. Lembremos, neste rumo, que os Sufis atribuem um poder sobrenatural intrínseco à própria palavra corânica (principalmente declamada ou recopiada), sem que seu sentido precise ser necessariamente compreendido literalmente. Outra ilustração do caráter inerentemente sobrenatural do texto corânico (na materialidade de sua escrita) é a prática comum tanto na África do Norte e Ocidental como dentre os próprios Malês da Bahia (como foi relatado por Antônio Monteiro), de ingurgitar a água embebida da tinta do texto corânico depois da lavagem das tábuas usadas na reprodução dos versículos sagrados.

Porém, isso não exclui ou diminui o valor enunciativo de um projeto sociopolítico, constitutivo da prática discursiva contida no ato de recepção e retransmissão do texto corânico. Pelo contrário, a reprodução do texto corânico, fiel ou refigurada, é, não apenas um catalisador para a conformação do projeto político existente no estado ideal na revelação divina, mas antes, a sua própria emanação. Se, por exemplo, uma prece roga pela Justiça Divina, é porque essa justiça se encontra indefinidamente ins- crita nos desenhos divinos e, portanto, deve ser desejada e exortada.

\section{A re-vivência dos tempos corânicos}

Para entender essa importância do texto corânico no imaginário islâmico, talvez seja necessário lembrar que o profeta Maomé, ao contrário dos fundadores de outras religiões, não realizou nenhum milagre espetacular, a não ser, justamente, a recepção da revelação divina materializada no texto corânico. Com efeito, segundo o entendimento místico islâmico, o Alcorão é a fala eterna e incriada de Deus, não inspirada, mas sim transmitida literal e fielmente através do Arcanjo Gabriel. A revelação constitui, portanto, um marco divino que estabelece o ato de nascimento da Umma, uma comunidade indefectível, universal, atemporal e até espacial (na medida que ela pode ser, e é, transnacional e trans-histórica), cuja natureza é ao mesmo tempo política, jurídica, organizacional, espiritual e filosófica.

O alcorão representa, assim, tanto o princípio da História da nação islâmica (limitada inicialmente à península arábica) como seu próprio telos, seu quadro de medição auto-referente e um evento histórico significativo que ia reformular o devir de toda a Humanidade. De fato, vale observar que o aparecimento da nova comunidade correspondia, efetivamente, a uma re-configuração geo-estratégica crucial, marcada pelo declínio das potências de então (os impérios persa e bizantino principalmente), a transformação de todo o mapa político e militar mundial e o esboço de uma nova realidade inter-nacional (no sentido das relações entre nações) cujos desdobramentos são visíveis até hoje.

Não se trata de retraçar, aqui, a epopéia política ou militar da Umma islâmica, mas cremos que não se deve ignorar a importância do componente histórico factual na construção de um projeto social universal (ainda que através de um discurso mítico) que, como se pode constatar nos dias de hoje no Oriente Médio, no episódio da Revolta dos Malês no Brasil, na história do movimento cívico norteamericano ou na dolorosa travessia dos povos africanos e asiáticos para a libertação do jugo do imperialismo europeu, serviu e continua servindo de catalisador revolucionário e libertário tanto subjetivo como tático-estratégico.

Porém, no âmbito de uma abordagem mais pontual relativa ao "livro malês", subsídios de ordem discursiva-enunciativa do Alcorão seriam, certamente, de maior utilidade. Assim, há de destacar primeiro que o Alcorão, aquém de seu alcance místicoespiritual, representa uma experiência lingüística e filológica única. Revelado no dialeto da tribo de Maomé - o quraichi que não disponha então de regras gramáticas estruturadas e ainda menos escritas, o livro sagrado se tornará o referencial lingüístico supremo de centenas de milhões de pessoas no mundo e o quadro de pensamento e de organização 
tanto escatológica como social do sexto da população humana, propulsando assim um falar local submerso num mar de vernáculos regionais, ao ranking das línguas mais complexas e mais ricas do mundo.

A originalidade desse fenômeno reside no fato do Alcorão acabar constituindo a base gramatical e lingüística do quadro de representação simbólica que, justamente, o gerou; ou seja, o fruto acabou conformando a estrutura da própria árvore que o produziu. Logo depois de ter sido con- (ou re) cebido no vernáculo árabe / quraichi (ainda sem regras estabelecidas), ele se tornou o parâmetro canônico reflexivo que determina a validade deste mesmo código simbólico. O que quer dizer que enquanto produto da visão do mundo espelhada no árabe, ele se impôs como quadro mediador pelo qual essa própria estrutura imaginária e simbólica se relaciona doravante com o mundo.

Antropologicamente, isto explica a grande dificuldade de diferenciar o que é especificamente islâmico do que é propriamente árabe e legitima o caráter sagrado da língua árabe; como se aprendeu no "Islam Observed" de Geertz.7 Já no nível enunciativo discursivo, a consagração de regras lingüísticas eternas coroadas por uma aura divina (constitutivas da sua fala incriada) permite à narrativa corânica adquirir uma dimensão universal e atemporal, sustentada por um fundo semântico livre de qualquer limitação contextual e imune às variações históricas, sociais e políticas que, ordinariamente, determinam o devir e a evolução das línguas naturais.

Um outro fator que foi decisivo no processo de universalização da mensagem corânica e sua "atemporalização" diz respeito ao modo pelo qual o texto revelado foi compilado e organizado. As 114 Surates, ou capítulos, que compõem o Alcorão (subdivididas por sua vez de ayat - versículos) foram classificadas simplesmente de acordo com a sua ordem de comprimento decrescente sem se deter ao seu princípio unificador temático ou a sua seqüência cronológica. Todavia, este método ordenador, usual na época no mundo semítico, em seguida se revelou uma infalível estratégia discursiva de perenização dos ensinamentos corânicos. Na medida que a "descontextualização" do texto sagrado - o fato de o sentido das surates não ser mais diretamente ligado ao contexto social, políticos ou até natural do momento de sua revelação - permite a sua reinterpretação ad infinitum em função do quadro histórico da sua leitura e as condições sociais e culturais de sua recepção; no mais perfeito modelo espiral da "semiose infinita".

As estórias e os personagens bíblicos retomados no Alcorão, por exemplo, se desfizeram totalmente de sua ancoragem seqüencial histórica factual para adquirir uma sincronicidade absoluta que os torna contemporâneos (do tempo mítico), conterrâneos e naturais do mesmo mundo divino imutável e onipresente. Nessa lógica mítica atemporal, não há passado nem historicidade hegeliana, mas apenas a mesma cena original que se repete infinitamente em roupagens sempre atualizadas para comprovar a vontade de Deus e provar a fé de seus servos.

Profetas, reis, anjos, cidades e batalhas não são fatos passados ou protagonistas de episódios históricos acabados, mas sim uma "I'ibra" (ideal ou exemplo) a ser meditada pelos crentes, sem que isso ponha em questão a veracidade de sua existência; já que a própria existência "real" que experimentamos não passa de um reflexo da essência ontológica contida nos desenhos divinos e acessíveis apenas através de sua fala incriada. Pelo contrário, Babilônia é aqui, Faraós (palavra que em árabe é, sintomaticamente, um adjetivo) e Imperadores romanos são os poderosos de hoje e de sempre - a ordem escravocrata brasileira, os impérios coloniais ou, quiçá, até a atual ditadura neoliberal! Esta abordagem específica do Tempo é fundamental para a compreensão da natureza complexa da enunciação corânica e de sua refiguração malê. Apesar do tempo mundano ser orientado entre a criação e o fim do mundo, os elementos lingüísticos gramaticais, como os advérbios temporais ou espaciais usados, revestem significados múltiplos, muitas vezes escatológicos, que só tornam o texto mais imune ainda a toda tentativa cronológica diacrônica reducionista. ${ }^{8}$ É esse destacamento do texto corânico, a libertação de suas condições inicias de produção que ia permitir, justamente, seu uso místico popular abstrato comum nos países muçulmanos como talismã ou amuleto, ou ainda como modelo político e social a ser seguido ou meditado em todas as épocas e todas as circunstanciais que a Umma pode atravessar. Resistência política, injustiça social, lutas pela independência, epidemias ou catástrofes naturais são "re-vivências" do tempo corânico onipresente e eterno; até o dia do Juízo Final.

Assim, o "livro malê" pode ser entendido simultaneamente como Hijab (Talismã) individual ou como projeto social e político coletivo para a fundação de uma comunidade islâmica no novo mundo, enfatizada na implantação de uma semente (descendência) abençoada no solo hospedeiro; tornando-o assim a Terra Prometida. Os Malês seriam, nessa lógica, os novos Hebreus, missionários encarregados da instauração do Reino de Deus na Terra, enquanto o poder colonial seria uma reencarnação da opressão faraônica; já que a ação verdadeira não estaria acontecendo aqui e agora (conceitos sem sentido no discurso mítico), mas sim se "refigurando" a partir da cena original da provação e da comprovação.

\section{As esferas de significação de uma língua sagrada}

Numa tentativa de apreciação geral desses mecanismos discursivos enunciativos próprios ao texto corânico, indispensável para a interpretação adequada do "livro malê", sugerimos o exame das consagradas teses de Mohammed Arkoun (contidas na tradução francesa do Alcorão por Garnier Kasimirski ${ }^{9}$ ). Partindo de princípios semiológicos 
hjelmslevianos, M. Arkoun propõe a adoção de uma perspectiva "especificante" do Alcorão, que não se limita a fatos lingüísticos isolados, mas considera o texto sagrado na sua totalidade enquanto sistema de relações internas, na medida que a significância é produto dessas relações e não de unidades artificialmente isoladas.

Uma abordagem semelhante já tinha sido proposta pelo islamólogo japonês Toshihiko Izutsu em seu estudo dos conceitos-chave que dizem respeito a Deus e ao Homem no Alcorão, para conceptualizar a visão de mundo relativa a esse discurso e estabelecer uma semântica específica ao Alcorão. Todavia, o projeto maior de M. Arkoun objetiva a elaboração de uma verdadeira tipologia da linguagem sagrada; partindo da constatação que o Alcorão constitui um universo coerente de signos, metáforas, mitos, metonímias e ritos apropriados e não apenas uma seqüência compósita de enunciados autônomos.

De fato, ao se basear numa leitura da totalidade das relações internas de sentido, esse tipo de estudo consegue transcender a dinâmica típica à língua árabe para alcançar a dimensão simbólica corânica inerente à filosofia e à estética que fundamentam a consciência islâmica. Não há dúvida que a análise deve ser feita dentro de uma lógica lingüística árabe para poder ter uma perspectiva abrangente de todos os elementos constitutivos da rede de significantes que compõem a paisagem semântica e a ecologia cognitiva do Alcorão, como a poética, a acústica, a história da língua, etc.

Mas se deve ficar atento principalmente ao fato que os conceitos corânicos buscam e desdobram seu significado dentro do próprio Alcorão, de tal maneira que a maioria das entidades lingüísticas deste não podem ter uma existência independente fora do universo simbólico do Livro sagrado e fora da rede de significados que estrutura a intertextualidade própria ao Alcorão. ${ }^{10}$

É claro que qualquer termo presente no Alcorão pode ser interpretado em vários níveis, do lexicográfico ao filosófico, passando pelo ético, psicológico e tantos outros. Mas para poder ter acesso ao seu significado profundo é necessário, de certo modo, não "ler" o termo, mas sim percebê-lo na globalidade textual do Alcorão, "tudo o que essas palavras recebem da intenção significante global do texto e tudo o que elas trazem, em retorno" para orientar a dinâmica do discurso corânico (Cf. Arkoun).

Segundo essa lógica, para ter acesso ao sentido do Alcorão e à configuração semântica interna de seu discurso, é preciso renunciar a toda leitura linear que privilegia a acepção comum e a lógica predominantemente gramatical. Mesmo se as surates forem classificadas numa ordem temática (como é o caso no "Livro malê"), continua sendo indispensável superar o aspecto retórico formal para descobrir a sua estrutura interna; na medida que o discurso corânico é uma orquestração intertextual semântica e acústi- ca de conceitos-chave cuja extensão cabe no próprio universo simbólico do Alcorão.

Numa semiótica da enunciação tradicional, admite-se que "as relações entre diferentes pontos da superfície textual, entre textos contíguos no mesmo espaço ou entre textos presentes e ausentes, numa espécie de terceira dimensão, valem tanto ou mais no processo de produção de sentido do que a própria sucessão linear de signos estruturalmente organizados" (Pinto, Milton, J. As Marcas lingüísticas de enunciação. p. $14^{11}$ ). Já com relação ao texto corânico na sua forma original ou "refigurado", como é o caso do "Livro Malê", essa relação é ela mesma de ordem simbólica mítica específica e inerente ao próprio discurso corânico.

Assim, na tentativa de desvelar a estrutura interna do Alcorão, M. Arkoun propõe uma leitura vertical do vocabulário corânico: o significado do discurso do Livro sagrado seria, segundo essa óptica, organizado num movimento ascendente / descendente através de quatro esferas de significação, coroadas pelo conceito supremo de Deus. As esferas em questão são as do Mistério, da Escatologia, dos Céus e da Terra, e vão do menos perceptível ao mais perceptível, do infinito ao finito, do perdurável ao perecível, seguindo a trajetória da Revelação que ordena o mundo em realidade oculta imperceptível e misteriosa (da qual o Além faz parte) e em realidade material composta, notadamente, de bens materiais ou maravilhas da Terra. Sendo que a idéia de "maravilhas da Terra", todavia, não deve ser entendida num sentido marxista de produção e acumulação capitalista, mas sim enquanto dom divino alcançado pela ação justa voltada para os ensinamentos divinos.

O que significa que não é possível alcançar o significado "verdadeiro" do texto corânico sem dispor desse saber mítico-metalingüístico relativo ao discurso do Livro Sagrado, já que a palavra divina instaurou um modo de conhecimento característico do estar-no-mundo-criado distinto do estar-no-mundo-objetivo. Se para este segundo modo de conhecimento a percepção "objetiva" pretende superar a dimensão imaginária de nossa vivência e fazer coincidir as realidades significantes com as realidades significadas, o discurso corânico, por sua parte, busca sua significância no quadro de representação simbólica que lhe é próprio, produto da língua árabe remoldada na esfera mítica-religiosa que intermedeia a relação entre o Homem e o mundo. Língua e pensamento se desdobram, assim, solidariamente num universo de significação que se refere em última instância ao divino, através de associações remissivas movidas por palavras-símbolos relativas às quatro esferas anteriormente descritas, subordinadas à infinitude do conceito supremo - Deus.

\section{A linguagem do mito}

Um outro aspecto essencial para a compreensão da lógica corânica contida no texto malê e constitutiva 
de seu projeto sociopolítico é a natureza mítica de seu discurso enquanto expressão simbólica localizada de realidades originais universais..$^{12}$ Se a passagem da linguagem concreta para a linguagem mítica equivale à transformação da palavra-signo em palavra-símbolo no processo de conformação da consciência humana, tal passagem significa, no contexto da Revelação islâmica, a edificação de um ideal de totalidade, de perfeição e de infinitude cujo plano de projeção aponta para a comunidade original fundada na vontade de instaurar a ordem atemporal divina.

De fato, a consciência mítica não idealiza o devir humano em termos de progresso ou de historicidade unidirecional, nem de espacialidade quantificável e mensurável, já que tanto o ontológico como o fenomenológico são considerados como simples manifestações parciais do divino. Portanto, o objetivo da própria existência humana não é de comprovar as evidências, verdades e certezas divinas absolutas no modelo racional logocêntrico do "cogito ergo sum", mas sim alcançar a consciência sensível global do ato divino; ela mesma expressa em termos míticos e místicos. Aliás, há de assinalar que a própria idéia de comprovação no discurso mítico não pressupõe dúvida ou possibilidade de erro, mas apenas um exercício místico para atingir a capacidade de percepção da verdade.

Assim, na lógica mítica subjacente ao texto corânico refigurado no "Livro Malê", o episódio dos escravos africanos não deve ser considerado enquanto fato histórico situado num contexto econômico e político que tem um "antes" e um "depois", mas sim como atualização atemporal de uma virtualidade pregnante existente desde sempre nos planos divinos. Este princípio vulgarizado no Ocidente sob o conceito do "Escrito" / "Maktub" e, muitas vezes, interpretado como uma consciência trágica fatalista, não exclui a resistência ou a luta; pelo contrário! Já que Deus é justo e magnânimo, não há espaço conceitual possível para a dúvida no triunfo final da Verdade sobre a falácia, o erro e a injustiça. Portanto, é a recusa da luta e da resistência que deve ser atribuída à falta de fé e de certeza no poder divino e não a ação política ou militar.

Se a comunidade malê, enquanto desdobramento do ideal comunitário islâmico original (Umma), é inscrita na própria ordem do Divino, a sua concretização é um imperativo que o fiel, o crente, o submisso e/ou salvo por Deus ${ }^{13}$ tem a obrigação moral, ética, política e até estética (da vida) de concretizar - ou melhor, se deixar nela emergir num tipo de epifania inversa que não busca a comprovação da veracidade da palavra divina, mas sim a capacidade do fiel nela se inscrever para merecer a impressão divina. Ou seja, não há dúvida que esta comunidade existe e sempre existiu; o que se tem que comprovar é se os malês (ou todo outro projeto sociopolítico baseado no ideal comunitário islâmico) são o marco verdadeiro da conjunção certa que ia deixar transparecer a vontade divina.
A própria linguagem mítica é uma linguagem da certeza absoluta onde não cabe a dúvida nem são precisos métodos demonstrativos, dedutivos, indutivos ou outros. A certeza mítica que sustenta a narrativa corânica é reforçada mais ainda pela predominância da proposição nominal característica da língua árabe e pela tradição comunitária da organização social islâmica; sendo o Alcorão destinado não a ser lido individual e silenciosamente (ainda que pode o ser e o é), mas sim declamado coletivamente. Uma outra propriedade da linguagem mítica no Alcorão é a sua riqueza simbólica que a predestina a todo tipo de reformulação e reinterpretação atualizada e re-contextualizada. Mesmo quando se confronta a versículos descritivos da paisagem corânica (o paraíso, dos céus ou da geena), esses relatos devem ser interpretados num sentido simbólico imaginário cuja finalidade, igualmente às estórias bíblicas, é a "I'ibra" a meditar, refletir e legitimar a esperança na condição humana e na justiça final.

Assim, o campo de ação desse simbolismo corânico pode ser dividido em quatro eixos (que são amplamente observados no "Livro Malê" e podem servir de base numa eventual análise mais detalhada): o simbolismo da consciência do proibido, o simbolismo do horizonte escatológico, o simbolismo da comunidade e o simbolismo da vida e da morte. As articulações enunciativas e discursivas, apoiadas na força poética e sugestiva da língua árabe, desse simbolismo mítico instauram uma visão operacional perfeitamente adaptada à necessidade humana de acreditar na sua Salvação prometida, delimitando assim as possibilidades existenciais e ontológicas do Homem. Ao povoar o imaginário muçulmano de representações simbólicas e míticas, ela acaba elaborando mecanismos mentais cognitivos de resistência às veleidades invasivas da razão instrumental e do objetivismo materialista, fazendo triunfar a visão imaginativa e trans-histórica sobre a metafísica racionalista positivista.

Finalmente, destaquemos alguns efeitos de caracterização intrínsecos ao Alcorão, principalmente as enigmáticas letras isoladas do alfabeto árabe que iniciam certos versículos ("sin", "ya", "alef", "kaf", "lam" e "mim"). Expressões não idiomáticas, consideradas como um mistério semântico e lingüístico na exegese islâmica e que constituem um campo infinito de interpretações místicas reservadas aos estudos esotéricos.

\section{Uma comunidade complexa}

Além das propriedades já analisadas do texto corânico, não podemos deixar de salientar as peculiaridades do modo de enunciação específico ao Livro Sagrado e que acabam possibilitando as sua múltiplas refigurações temáticas situacionais adaptáveis a vontade aos mais diversos contextos de adversidade humana. Trata-se de sua complexidade e sua indeterminação enunciativa que o situam fora de 
qualquer regra semiótica tradicional, reforçam a sua estrutura mítica e enriquecem suas dimensões universal e atemporal. Categorias discursivas habituais como a progressão narrativa, a unidade textual ou a determinação do sujeito empírico, por exemplo, são simplesmente desconsideradas, enquanto formulações inusitadas são erguidas em regra discursiva típica ao Alcorão.

A natureza complexa da narrativa corânica pode ser observada em vários níveis da construção lingüística do Alcorão. O primeiro diz respeito à sua heterogeneidade exacerbada que o situa numa esfera enunciativa entre o divino, o mundano, o mítico e o trans-histórico. Além de seu caráter descontextualizado, atemporalidade e universalidade devido a seu modo de classificação formal, o texto corânico é constituído de várias camadas narrativas onde o referencial bíblico (na sua forma primitiva então em circulação ${ }^{14}$ na península arábica) revisado se mistura com as novas propostas surgidas no contexto político contemporâneo à Revelação. Desta forma, todo o Alcorão é permeado por uma impressão difusa de "diálogo" entre sujeitos e personagens de várias épocas e variados contextos sociais lingüisticamente integrados na forma impessoal nominal própria ao árabe. Já que, como é sabido, nesta língua, é possível se ter frases ou até parágrafos inteiros na forma nominal impessoal onde o sujeito empírico é difícil de situar.

O sujeito corânico, pois, é matéria de vários tratados de exegese islâmica e é marcado por uma forte polifonia e uma múltipla heterogeneidade enunciativa. ${ }^{15}$ Nunca se sabe claramente, por exemplo, se o sujeito empírico é Deus, o Arcanjo Gabriel (que é identificado ao Espírito Santo na tradição islâmica), o conjunto dos profetas, o próprio Maomé ou uma instância misteriosa de difícil acesso para a limitada mente racional. ${ }^{16}$ A complexidade é tão marcada que, muitas vezes, não se sabe nem quem é o sujeito empírico nem quem é o sujeito do enunciado; várias vozes se manifestam no mesmo versículo ou na mesma frase sem ordem aparente, algo que só um estudo lingüístico-teológico (ou talvez só a exaltação mística) podem definir.

O dialogismo radical e a polifonia generalizada são mais de que recursos retóricos instrumentais que permitem a multiplicação de variações de significância no Alcorão. É a expressão exacerbada do próprio modelo comunitário islâmico em seu desdobramento complexo e fractal, onde o menor e o maior, a parte e o todo se contém mútua e infinitamente. Sendo toda manifestação comunitária originária deste modelo, na verdade, a atualização da mesma essência islâmica encerrada no plano original.

Talvez um forte indício, neste sentido, seja o fato de o Levante Malê ter ocorrido durante o mês de Ramada, a época da Revelação, justamente! Ou seja, na lógica mítica-mitológica do espírito comunitário islâmico, não era um evento histórico acontecendo treze século depois da revelação maometana, mas sim a atualização da essência da Revelação Divina eterna e infinita. O que deixa claro, por outro lado, que o texto corânico não é considerado como "representação" de uma realidade, mas a Realidade em si que precede todas as atualizações humanas e mundanas do desenho divino.

Portanto, a idéia de comunidade contida na experiência discursiva corânica como em seus desdobramentos mundanos é, de certo modo, virtual:

a. na medida que ela é "modelada" discursivamente, a partir de um programa narrativo dado e é até "acessada" através desta mesma "interface" discursiva específica;

b. ela é virtual no sentido da sua pregnância e potencialidade infinita que se atualiza a cada vez que uma conjunção narrativa determinada se preste a tal evento. Nas duas situações, a dita comunidade é "configurada" ou "conformada" discursivamente e é o reflexo sensível e inteligível de uma essência narrativa que, por sua vez não é a "representação" de alguma realidade, mas a essência do que seria chamado "realidade" pelos paradigmas racionais, modernos e ocidentais.

\section{Texto, contexto e pré-texto}

Assim sendo, podemos concluir que uma comunidade desta natureza (ao mesmo tempo social, política e espiritual) não depende integralmente de um espaço real e concreto para acontecer. A sua existência, a sua "poiesis" e a sua "práxis", que transcendem os constrangimentos físico-espaciais necessários para seu devir ontológico se dão, primeira e ultimamente, no texto livro; cujos quadros simbólicos componentes de sua ecologia cognitiva servem de estrutura geral para a sua realização. Dinâmica que se pode ser conferida, total ou parcialmente, também na perspectiva maior da relação entre narrativas comunitárias e discursos organizadores da(s) identidade(s) de grupo de outras ordens.

De fato, partindo da premissa que todo trabalho de construção de uma identidade cultural equivale a um texto (social, cultural, histórico) e que a subjetividade é, de algum modo, uma modulação discursiva do mesmo fato (social, cultural, histórico), se pode afirmar (seguindo o princípio desta isometria entre subjetividade e discursividade) que o advento de qualquer texto enquanto enunciação de um projeto comunitário ou de uma especificidade identitária depende de um contexto (conjunto de condições sociais, culturais e históricas que possibilitam a emergência de uma realidade dada) e é tributário de um pré-texto: uma narrativa original que propicia a inteligibilidade do fato identitário comunitário - um tipo de catalisador semântico que possibilita a configuração do texto identitário e a emergência de seu estado de latência semiosférica inicial.

Ou seja, a construção de uma identidade comuni- 
tária minoritária específica pode se usar, inversamente, de discursos fundadores (étnicos, culturais, religiosos) como estratégia de afirmação de sua singularidade e como argumento de negociação contra-hegemônica na sua luta pelo poder simbólico. Os agentes (atores - autores) comunitários podem se auxiliar de várias e variadas linguagens sociais no afã de reformular dados pré-textos que possam servir a sua causa. Linguagens que constituem, neste sentido, dispositivos semânticos suscetíveis de conformar o projeto identitário minoritário e de aparatos éticos-estéticos para os grupos minoritários que recusam o status quo. O que significa que a questão da identidade minoritária não deve ser essencializada ou naturalizada, mas apreendida enquanto uma elaboração discursiva que se baseia numa multiplicidade de narrativas conjunturais. Famecos

\section{NOTAS}

1 [Do ár. murAbi+, lit.: 'aquele que vive em um ribat (fortaleza ou monastério)', i.e., 'eremita', 'monge';'guia religioso'.]S. m. a. Rel. Asceta religioso ou guia espiritual muçulmano. b. Restr. Membro de qualquer uma das comunidades religiosas e militares do Norte da África, de grande ascendência espiritual e política entre os berberes, esp. na época da expansão islâmica em direção à África ocidental (séculos XI-XIII). [Sin. ger., nas acepç. a e b: marabu, morabita e morabito.] c. P. ext. Local sagrado, associado à presença de um marabu (a), como o templo onde este realiza o serviço religioso, ou a sepultura em que está enterrado. (Dicionário Aurélio -Século XXI)

2 [Do ior. imalê, 'muçulmano'.] (Dicionário Aurélio-Século XXI)

3 "O ethos pode ser considerado como parte de um processo mais amplo de 'modelagem' em que o lugar e o tempo de uma interação e seu conjunto de participantes, bem como o ethos dos participantes, são constituídos pela projeção de ligações em determinadas direções intertextuais de preferência a outras. Maingueneau (...) dá o exemplo do discurso (discursos políticos, por exemplo) da Revolução Francesa, que foi modelada sobre o discurso republicano de Roma antiga em termos de lugar, tempo e 'cena' (no sentido de circunstâncias gerais do discurso), assim como dos participantes e do ethos dos participantes" Norman Fairclough: 207-208.

4 “...desde muitos séculos, o alfabeto árabe tem sido o traço cultural comum entre as grandes áreas mundiais do Islão. Na África negra, as línguas "islamizadas" se transcreviam, e ainda continuam a ser escritas, em carcteres árabes. É o caso, em particular, do fula, do haussá, do swahili, ainda que a romanização ganhe rapidamente terreno. A pronúncia do árabe sofre, naturalmente, uma profunda alteração sob influência negro-africana. Os empréstimos vocabulares constituem, com a escrita, a manifestação mais notável da arabização de línguas que, como o haussá ou o swahili, têm perto de metade de seu léxico constituída por empréstimos tomados à língua árabe (termos referentes à vida religiosa, à divisão do tempo, escritos e talismãs, idéias morais, ensino, leitura e escrita, vestuário e alimentação, vida administrativa, econômica e militar). No domínio da morfologia, a influência do árabe é menos evidente e mais sutil. Ela se exerce, às vezes, através do berbere. Tais contatos poderiam talvez explicar certas anomalias de sintaxe. Em certos casos, frases árabes inteiras foram adotadas, por decalque ou tradução mecânica. Essa influências do árabe sobre as línguas negro-africanas acarreta pelo menos quatro conseqüências principais: fixação pela escrita, enriquecimento léxico, precisão do vocabulário, difusão de grandes áreas de civilização panafricana. É, porém, essencial assinalar que essa arabização cultural não se acompanha de nenhum ä arabismo" político. Ainda a respeito dessa questão, poderemos lembrar que Léopold Sedar Senghor destacou, e com razão, três tipos de convergências (étnicas, artísticas e conceituais) entre árabo-berberes e negro-africanso" Vincent Monteil: 17-18.

5 Le conflit des interprétations. Essais d'herméneutique. Paris: Seuil 1969.

6 Nação ou comunidade religiosa que reúne todos os muçulmanos do mundo, num plano tanto real como espiritual.

\section{Geertz, Clifford.}

8 “... para o teólogo muçulmano, o tempo não é uma duração contínua, é uma constelação, uma via Láctea de instantes (tal como o tempo não existe, o que existe são apenas pontos)... Esta percepção descontínua do tempo não é mera subjetividade religiosa. Para toda a Comunidade muçulmana, o instante é como uma revocação autoritária da Lei, tão inevitável como inesperada". "Portanto, o primeiro trabalho de pensamento muçulmano ignora a duração contínua, $\mathrm{e}$ só encara átomos de tempo, instantes, ânât ( $\mathrm{pl}$. de ân), awqât (pl. de waqt, cf. Corão 15, 38). Não são estados". Louis Massignon: 12-16

9 Kasimirski, Garnier. Le Coran. Paris: Flamarion, 1970.

10 Com certeza isto não é exclusivo ao discurso 
corânico: “Vê-se que as coisas, tal como as conhecemos e percebemos, não possuem uma significação em si mesmas, imanente e essencial no sentido aristotélico, de caráter conceitual, a que se deu o nome de significado. De um ponto de vista estritamente materialista, não existe essa entidade abstrata chamada significado, mas sim remissivas de significante a significante, produzindo efeitos de sentido. Toda vez que se procuram significados, esbarra-se em outros significantes, num processo de tradução que foi chamado de semiose infinita e mais modernamente de intertextualidade" J. Milton Pinto: 16.

11 J. Milton Pinto.

12 "Le mythe est un récit traditionnel qui rapporte des événements arrivés à l'origine des temps et qui est destiné à fonder l'action rituelle des hommes d'aujourd'hui et, de manière générale, à instituer toutes les formes d'action et de pensée par lesquelles l'homme se situe dans son monde. Fixant les actions rituelles significatives, il fait connaître, quand disparaît sa dimension étiologique, sa portée exploratoire et apparaît dans sa fonction symbolique, c'est-à-dire dans le pouvoir qu'il a de dévoiler le lien de l'homme à son sacré". Paul Ricoeur: 121.

13 A palavra musslim (muçulmano) foi, na maioria das vezes, traduzida pelos orientalistas no sentido de "submisso" ou "entregue" a Deus. Porém, divido à natureza fluida e imprecisa da semântica árabe, a mesma palavra pode ser (e é) entendida enquanto "salvo" por Deus. Na língua árabe, as palavras "paz", "salvação" e "entrega / submissão" tem a mesma raiz etimológica e sentidos bastante próximos em seus vários e variados usos e acepções.

14 "Aparentemente, o Corão e a Bíblia são próximos. O islamismo não se desenvolveu na região em que estavam presentes as tradições judaica e cristã? Acontecimentos como a criação e muitos personagens bíblicos são utilizados ou citados pelo Corão. Entretanto, a apresentação dos personagens e a interpretação dos fatos são radicalmente diferentes. Os relatos, tal como são apresentados no Corão, são influenciados pelos textos apócrifos que circulavam durante os primeiros séculos cristãos, ricos em histórias e narrativas maravilhosas. Os cristãos os baniram do Novo Testamento" Jeannine Siat: 84.

15 "A heterogeneidade enunciativa manifesta-se num texto em dois planos distintos: como polifonia ou heterogeneidade mostrada caracterizada pela manifestação explícita de vozes, citadas pelo autor empírico do texto, tendo em vista a realização de seus interesses comunicacionais, e como plural do texto ou heterogeneidade constitutiva, constituída pelo entrelaçamento de uma pluralidade de citações emigradas de outros testos pré-existentes, segundo restrições histórico-culturais sobre as quais o autor empírico do texto não tem controle racional" J. Milton Pinto: 18.

16 “O Alcorão não é um livro no senso comum; é a coleção das palavras de Deus, reveladas de tempos em tempos, durante vinte e três anos, a seu mensageiro, escolhido entre os seres humanos. O Soberano dá Suas instruções a Seu vassalo; portanto, há certas nuances compreendidas e implícitas; há repetições e até mesmo mudanças nas formas de expressão. Deste modo, Deus fala às vezes na primeira pessoa e às vezes na terceira. Ele diz "EU", bem como "Nós" e "Ele", porém, jamais "Eles". É uma coleção de revelações enviadas de ocasiões em ocasiões (...) Ele possui diretrizes para todos, em todos os lugares e para todos os tempos" Samir El Hayek: XV.

\section{REFERÊNCIAS}

EL HAYEK, Samir. O Significado dos versículos do Alcorão Sagrado. SP: Marsam Editora, 1994.

FAIRCLOUGH, Norman. Discurso e Mudança Social. Brasília: Editora UNB, 2001.

GEERTZ, Clifford. Islam Observed: Religious Development in Morocco and Indonesia. Chicago: The University of Chicago Press, 1971.

KASIMIRSKI, Garnier. Le Coran. Paris: Flamarion, 1970.

MASSIGNON, Louis. Le Temps dans la pensée islamique. Paris: Seuil, 1983.

MONTEIL, Vincent. O Islão na África Negra. BA: Afro-Ásia n. 4-5, 1967.

MONTEIRO, Antônio. Notas sobre negros malês na Bahia. Salvador: Ianamá, 1987.

PINTO, J. Milton. As Marcas lingüísticas de enunciação. RJ: Numen, 1994.

REIS, J. José. Rebelião escrava no Brasil. SP: Companhia das Letras. 2003.

RICOEUR, Paul. Le conflit des interprétations. Essais d'herméneutique. Paris: Seuil, 1969.

SIAT, Jeannine. Religiões monoteístas. RJ: Zahar, 2000. 